\title{
METODE TAHFIDZUL ALQURAN DI RUMAH TAHFIZH MIFTAHUL JANNAH KOTA MEDAN
}

\author{
Fatimah Rahma ${ }^{1}$,Darliana Sormin ${ }^{2}$,Dr. Candra Wijaya,M.Pd. ${ }^{3}$ \\ fatimahrahma24@yahoo.co.id \\ darliana.sormin@um-tapsel.ac.id
}

\begin{abstract}
The method applied in the Tahfzih Miftahul Jannah House in the process of memorizing the Koran is: the method of tasmi ', wahdah, takrir and sima'i. the method of 'mummy' is divided into two, namely the 'morning deposit' and the repetition of the 'mule' in the afternoon. Metodetasmi 'is an activity of depositing the memorization of the Koran of the santri to one of the ustaz or ustzah respectively. The method of wahdah, takrir, and sima'I is a method that is applied by santri individually to seek memorization before depositing it to the cleric or cleric.
\end{abstract}

Keywords: Method, Tahfiz Alquran, Miftahul Jannah

\begin{abstract}
Abstrak Metode yang diterapkan di Rumah Tahfzih Miftahul Jannah dalam proses menghafal Al-Quran adalah: metode tasmi ', wahdah, takrir dan sima'i. metode 'mummy' dibagi menjadi dua, yaitu 'deposit pagi' dan pengulangan 'bagal' di sore hari. Metodetasmi 'adalah kegiatan menyetor hafalan Al-Quran para santri ke salah satu ustaz atau ustzah masing-masing. Metode wahdah, takrir, dan sima'I adalah metode yang diterapkan oleh santri secara individu untuk mencari hafalan sebelum disimpan ke ulama atau ulama.
\end{abstract}

Kata kunci: Metode, Tahfiz, Miftahul Jannah

\section{PENDAHULUAN}

Alquran merupakan kitab suci umat Islam yang diturunkan kepada Nabi Muhammad saw yang berisi petunjuk serta rahmat bagi seluruh alam. Alquran juga merupakan sumber dari segala ilmu. Ilmu-ilmu umum atau ilmu-ilmu agama khususnya, semua terdapat dalam Alquran. Oleh sebab itu, semua kurikulum pendidikan seharusnya merujuk pada Alquran serta hadis-hadis nabi tentunya.

\section{Banyak keistimewaan-keistimewaan} Alquran dibandingkan dengan kitab-kitab lainnya, salah satu keistimewaan tersebut adalah adanya penjaminan keabsahaan Alquran hingga akhir khayat oleh Allah swt. Namun hal tersebut bukan berarti umat muslim tidak perlu bertanggung jawab lagi dalam memelihara keabsaahan Alquran tersebut. Salah satu cara yang bisa dilakukan untuk menjaga keabsahan Alquran adalah dengan cara menghafal, mempelajari dan mengamalkannya.

Dalam Islam, belajar merupakan suatu kewajiban bagi setiap muslim yaitu dari buaian sampai ke liang lahat. Oleh sebab itu, Alquran sebagai kitab suci umat Islam serta sebagai sumber pokok seluruh ilmu pengetahun seharusnya diajarkan kepada peserta didik mulai dari sejak dini.

Pembelajaran Alquran diberbagai lembaga pendidikan saat ini dilakukan dengan 
bermacam-macam pembelajaran, seperti Jannah adalah pada jam 06.00-07.30, 14.00pembelajaran tahfizh dan lain sebgainya. 17.30 dan 07.15-21.30. Sedangkan metode Tahfizh merupakankata kata yang berasal dari yang diterapkan sangat beragam, salah satunya bahasa Arab hafiza-yahfazu-hifzan yaitu selalu adalah metode takrir yaitu metode pengulangan, ingat dan sedikit lupa. ${ }^{1}$ Tahfizh Alquran biasanya metode ini diterapkan oleh peserta merupakan kegiatan menghafal Alquran dari didik yang masih pemula dalam menghafal beberapa ayat hingga 30 juz. Namun sangat Alquran. Selain itu, metode wahdah juga disayangkan banyak yang menghafal Alquran diterapkan di Rumah Tahfizh Miftahul Jannah berhenti menghafal sebelum selesai menghafal 30 juz. Salah satu faktor penyebab hal tersebut adalah karena tidak tepatnya metode yang dilaksanakan.

Setiap peserta didik tentu memiliki IQ yang berbeda-beda, tidak semua peserta didik memeliki daya ingatan yang kuat. Oleh sebab itu, ke profesinalan seorang pendidik dalam menerapkan suatu metode dalam menghafal Alquran sangat mempengaruhi keberhasilan anak didik dalam menghafal Alquran. Meskipun pada dasarnya setiap orang pasti memiliki metode tersendiri dalam menghafal Alquran. ini yaitu oleh peserta didik yang sudah seniorsenior.

Dengan metode-metode tersebut, Rumah Tahfizh Miftahul Jannah kini telah mencetak hafizh-hafizh Alquran dengan jangka waktu belajar kurang dari 2 tahun.Adapun peserta didik atau santri-santri yang sudah menyelesaikan hafalannya 30 juz dengan jangka waktu yang cukup singkat serta memiliki hafalan yang kuat adalah Rizaul Abror Siregar: menyelesaikan hafalannya selama 1 tahun 1 bulan, Jen agus Perry: 1 tahun 3 bulan, dan M. Ariq Hibrizi: 1 tahun 1 bulan.

Berdasarkan paparan di atas, maka

Berdasarkan observasi awal peneliti, Rumah Tahfizh Miftahul Jannah merupakan tempat menghafal yang peserta didiknya memiliki usia yang beraneka ragam seperti tingkat SD, MTS, MA bahkan sampai ke perguruan tinggi. Adapun peserta didik yang datang mendaftar ke Rumah Tahfizh Miftahul Jannah semuanya diseleksi terlebih dahulu kemudian di tempatkan di kelas yang sesuai dengan kemampuannya.

Adapun waktu menghafal yang dilaksanakan di Rumah Tahfizh Miftahul

peneliti tertarik untuk meneliti lebih dalam lagi mengenai penerapan metodemenghafal yang dilaksanakan di Rumah Tahfizh Miftahul Jannah dengan judul METODE TAHFIZH ALQURAN DI RUMAH TAHFIZH MIFTAHUL JANNAH.

\section{METODE}

Jenis penelitian ini adalah Penelitian Kualitatif Deskritif, yaitu penelitian yang bermaksud untuk memahami fenomena tentang apa yang dialami oleh subjek penelitian misalnya perilaku, persepsi, motivasi, dan 
dengan cara deskripsi dalam bentuk kata-katan dan bahasa, pada suatu konteks khusus yang alamiah dan dengan memanfaatkan berbagai metode alamiah.

Adapun tempat penelitian sesuai dengan judul penelitian adalah di Rumah Tahfizh Miftahul Jannah yang beralamat di Jl. Sosro No. 106 Medan Tembung. Sedangkan waktu penelitian dimulai dari bulan september 2017 sampai Desember 2018.

Adapun analisa data yang digunakan dalam penelitian ini adalah analisa data model Miles dan Huberman yang terdiri dari tiga jalur kegiatan yang terjadi secara bersamaan yaitu : reduksi data, penyajian data dan kesimpulan/verifikasi. Reduksi data diartikan sebagai pemilihan, pemusatan perhatian pada penyederhanaan pengabstrakan dan transformasi data "kasar" yang muncul dari catatan-catatan tertulis di lapangan. Dan penyajian data yaitu peneliti menyajikan sekumpulan data atau informasi yang memberi kemungkinan adanya penarikan kesimpulankesimpulan dan pengambilan tindakan terhadap data yang telah diperoleh. Sedangkan penarikan kesimpulan merupakan kegiatan analisa yang ketiga, kesimpulan awal mula-mula belum jelas, tetapi kemudian meningkat menjadi lebih terperinci, sedangkan kesimpulan-kesimpulan akhir atau final akan muncul setelah penelitian atau pengumpulan data berakhir dilaksanakan peneliti, dan bergantung pada besarnya kumpulan-kumpulan catatan lapangan, pengkodeannya dan kecakapan peneliti.
Berdasarkan hasil penelitian yang peneliti lakukan, ada beberapa metode yang dilaksanakan di Rumah Tahfizh Miftahul Jannah, salah satunya adalah metode tasmi'Metode ini dibagi menjadi dua yaitu: setoran dan ulangan. Tasmi' setoran yang dimaksud dalam penelitian ini sebagaimana hasil observasi peneliti adalah seluruh santri wajib menyetorkan hafalan yang belum pernah santri hafal kepada ustadz atau ustadzahnya masing-masing. Kegiatan ini berlangsung dari jam 06.00-07.30. Adapun metode tasmi' ulangan adalah kegiatan tasmi' dengan menyetorkan hafalan yang sudah pernah di hafal kepada salah seorang ustadz atau ustadzahnya, dan kegiatan ini berlangsung dari jam 16.00-17.30. Untuk tasmi' setoran hafalan baru, santri-santri wajib menyetorkan hafalannya sebanyak satu halaman setengah setiap hari, sedangkan untuk tasmi' ulanagan, seluruh santri wajib menyetorkan ulangannya sebanyak dua maqra' yaitu sekitar tiga lembar setiap harinya selain dari ulangan pribadi masing-masing.

Sebelum kegiatan tasmi’ berlangsung, peneliti menemukan bahwa proses tasmi' di Miftahul Jannah terlebih dahulu dimulai dengan membaca sholawat kepada nabi saw serta membaca sepotong doa yang dibimbing oleh ustadz atau ustadzahnya masing-masing, kemudian dilanjutkan dengan kegiatan tasmi' yaitu setoran hafalan baru, setelah seluruh santri selesai menyetor hafalan, kegiatan tahfizh ditutup dengan pembaca doa bersama-sama.

\section{HASIL \& PEMBAHASAN}


Hal ini senada dengan pernyataan dari ustadz Ahmad Ali:

Hal ini senada dengan yang dijelaskan oleh ustadz AhmadAli:

Sistem belajar yang dilaksanakan di Rumah Tahfizh ini ada dua yaitu setoran dan ulangan, setoran dilaksanakan pada pagi hari karena pada pagi hari pikiran anak-anak masih segar untu belajar yaitu pada jam 06.00-07.30. Untuk ulangan dilaksankan di sore hari tepatnya sesudah sholat Ashar sampai jam 17.30. untuk setoran baru, anak0anak diwajibkan menyetor hafalan sebanyak satu halaman setengan setiap hari dan untuk ulangan yaitu dua maqra'. Target yang harus dicapai santri di sini adalah wajib kahatam atau selesai 30 juz dalam waktu dua tahun paling lama dan alhamdulillah santri-santri kita di sini sudah ada yang menyelesaikan hafalannya dalam waktu kurang lebih satu tahun.

Selain metode di atas, santri-santri juga menggunakan beberapa metode menghafal lainnya seperti: 1 . Metode wahdah, metode ini yang para santri ketika sedang menghafal Alquran sendirian yaitu sebelum menyetornya pada ustadznya. Mereka menghafal ayat Alquran ayat demi ayat, seorang santri tidak akan menambah hafalannya ke ayat selanjutnya sebelum ia hafal betul ayat yang pertama, setelah selesai menghafal ayat yang pertama kemudian pindah ke ayat yang ke dua, dan seorang santri juga tidak akan menghafal ayat yang ke tiga sebelum ia betul-betul hafal ayat yang ke dua dan seterusnya, hingga hafalan santri tersebut cukup satu halaman. 2. Metode Tikrar. Metode Tikrar yaitu seorang santri menghafal ayat Alquran secara berulang-ulang, sehingga huruf-huruf dan baris-baris ayat Alquran tersebut mudah diucappkan oleh santri kemudian baru ayat tersebut dihafal. Metode ini bibasanya dilaksanakan oleh santri yang masih pemula dalam menghafal Alquran, namun ada juga santri senior yang melaksanakannya. 3 . Metode sima'i yaitu seorang santri menghafal Alquran setelah mendengarkan bacaan seseorang yang dianggap bagus hafalannya, baik secara langsung maupun melalui alat media seperti MP3 Alquran dan lain sebagainya. Sebagaimana dijelaskan oleh Isra' Yunita:

Sebelum mulai menghafal, saya selalu baca doa terlebih dahulu, kemudian saya hafal ayat-ayat yang akan saya setorkan pada ustadzah. Biasanya saya setoran satu halaman setengan dan terkadang satu lembar. Agar lebih mudah menghafal dan tidak macetmacet ketika setoran nanti bisanya saya menghafal ayat-ayat Alquran satu persatu dan ustadzah juga marah kalau saya menghafal sekaligus, "harus satu persatu ayatnya dilancarkan."Satu-satu ayatnya dihafal kak, nanti susah melancarkannya"itu yang selalu ustadzah katakan pada kami. Tapi terkadang saya juga menghafal 
dengan metode Tikrar, ini saya pelajari dari guru saya di pesantren dulu sebelum ke Miftahul Jannah ini, biasanya saya mengulang-ulang hafalan tu sebanyak 41 kali dan untuk menghitungnya saya tilis di buku tulis, supaya tidak salah hitung. Ini juga sangat membantu dalam melancarkan hafalan saya.

Mariani juga menambahkan:

Tajwid sama makhrajul hurup saya masih banyak yang salah, kalau maju ke depan pasti selalu kena tegur, "tengok panjangnya kak, dengungnya mana" itu yang paling sering dan yang paling saya ingat kata-kata ustadzah kalau saya sudah maju. Tapi sekarang saya sudah beli MP3 Alquran, jadi sebelum mulai menghafal, saya terlebih dahulu mendengarkan bacaan Alqurannya dari MP3 tersebut jadi tidak salah hafal lagi sekarang dan tidak kena marah ustadzah lagi.

Dari penjelasan di atas dapat disimpulkan bahwa metode yang digunakan dalam menghafal Alquran di Rumah Tahfizh Miftahul Jannah adalah metode tasmi, ulangan, metode wahdah, tikrar serta sima'i.

Sebuah proses pasti memiliki hambatan dan rintangan, begitu juga dengan proses menghafal. Tidak semua perjalanan santri dalam menghafal berjalan dengan baik, ada beberapa hambatan-hambatan yang harus dilalui. Bagi yang berhasil melalui hambatan tersebut pasti akan memperoleh kesuksesan di Akhir, namun bagi yang tidak sanggup bertahan dalam hambatan tersebut, maka ini adalah salah satu penyebab dari gagalnya seseorang mendapat gelar hafiz atau hafizah.

Dalam penelitian ini ada beberapa hal yang peneliti temukan yang menjadi penghambat santri dalam proses menghafal Alquran di rumah tahfizh Miftahul Jannah yaitu: 1. Kurangnya kesungguhan santri dalam menghafal: para santri memiliki kemauan yang kuat dalam menghafal namun dalam kesungguhan sebagian mereka masih sangat kurang, contohnya ketika peneliti bertanya mengenai keinginan mereka dalam menghafal Alquran, salah satu santri memberi jawaban yang membuat peneliti sangat terkagum yaitu "saya ingin membahagiakan orangtua saya dengan menjadi hafizhah 30 juz dan saya janji tidak akan menikah sebelum selesai menghafal 30 juz." Namun dalam hasil observasi peneliti, beberapa santri ada yang tidur pada yang bukan jam tidur dan peneliti juga menemukan beberapa santri yang sedang memegang Alquran di tangannya, namun ketika peneliti amati lebih dekat ternyata santri tersebut sedang melamun. Hal tersebut membuktikan bahwa kesungguhan santri dalam menghafal Alquran masihharus terus ditarbiyah.

2. Kurangnya pengawasan terhadap keseharian santri. Selama dalam penelitian ini, peneliti berusaha untuk mengamati berbagai kegiatan santri. Manajemen waktu santri terlihat sangat 
teratur, tidak ada waktu yang terbuang sia-sia, mulai dari jam 03.30 yaitu jadwal paling lama bangun pagi sampai jam 23.00 yaitu waktu tidur bagi yang tidak sedang menghafal. Menurut hasil penelitian ini, guru atau tenaga yang membimbing para santri tidak full di asrama meskipun sebenarnya tinggal di asrama, namun memiliki kegiatan atau tugas yang lain di luar asrama, sehingga ketika guru atau ustaz/ustazahnya sedang keluar, sebagian santri tidak menggunakan waktu menghafalnya untuk menghafal namun sibuk dengan berbagai kegiatan yang tidak seharusnya dilaksanakan pada jam tersebut. Sebagaimana diketahui bahwa yang namanya anak-anak tentu tidak semua memiliki kesadaran untuk menghafal secara mandiri.

3. Fasilitas yang kurang memadai. Rumah Tahfizh miftahul Jannah pada saat ini baik yang muqimmaupun regular sekarangsudah berjumlahlebih dari 200 santri, baik laki-laki maupun perempuan dan menurut data yang peneliti peroleh masih banyak santri yang ingin mendaftar ke Rumah Tahfizh Miftahul Jannah ini, namun belum bisa di terima disebabkan ruangan yang belum mencukupi. Sehingga santri yang ingin mendaftar terpaksa menunggu daftar antrian.
Adapun faktor pendukung dalam menghafal Alquran di RumahTahfizh Miftahul Jannah yang peneliti temukan adalah :

1. Kemauan santri yang tinggi.

Kemauan merupakan modal utama dalam melaksanakan berbagai kegiatan, begitu juga dengan menghafal. Tanpa adanya kemauan dari diri seorang santri, keberhasilan akan sangat sulit diraih olehnya meskipun dukungan dari eksternal sangat kuat. Hal ini lah yang peneliti lihat dari santri-santri Rumah Tahfizh Miftahul Jannah. Meskipun banyak rintanganrintangan dalam menghafal, santri-santri terus mencoba untuk tetap bertahan. Cobaan dalam menghafal Alquran tentu berbeda dengan cobaan-cobaan orangorang yang sedang menuntut ilmu (tidak menghafal Alquran), seperti adanya hafalan yang susah untuk diingat, sulitnya dalam istiqamah murajaah, kesungguhan yang sering naik turun, ditambah lagi hukuman-hukuman yang bermacam ketika proses belajar, tidak adanya uang saku dan lain sebagainya. Mungkin beratnya cobaan menghafal Alquran tidak bisa peneliti ungkapkan dengan sempurna dalam penelitian ini, namun bagi yang sudah mengalami, tentu paham dengan yang dimaksud oleh peneliti. Kemauan santri yang kuat di Rumah Tahfizh Miftahul Jannah ini lah salah satu pendukung dari keberhasilan mereka dalam menghafal Alquran.

2. Adanya kegiatan ekstrakurikuler santri 
Menurut hasil penelitian ini, para santri Rumah Tahfizh Miftahul Jannah tidak hanya menghafal Alquran saja, namun dibekali dengan berbagai ilmu pengetahuan yang bertujuan untuk memantapkan hafalan para santri seperti adanya kegiatan ekstrakurikuler tahsin yang dilaksanakan setiap malam kamis. Para santri serta guru-guru seluruhnya memiliki hak untuk mengikuti kegiatan ini. Ekstrakurikuler ini di ampu oleh ustaz Fahrurrazi al-Hafizh, yaitu guru besar bidang tahsin di Kota Medan. Selain itu, ekstrakurikuler mabit juga dilaksanakan di Rumah Tahfizh Miftahul Jannah yaitu kegiatan malam bina iman dan taqwa yang dilakukan dalam sekali seminggu, kegiatan ini bertujuan untuk membina dan membangun kepribadian dan jiwa para santri agar sesuai dengan ajaran-ajaran agama Islam.

3. Adanya dukungan dari para tenaga pendidik

Ada istilah unik yang peneliti temukan dalam lembaga ini, dan istilah tersebut telah di tarbiyah kepada seluruh guru-guru, yaitu istilah "jihad" semua tenaga pendidik yang ingin ikut berjuang untuk mencerdaskan anak-anak bangsa dalam lembaga ini harus memiliki kriteria jihad yaitu berjuang di jalan Allah swt dan membelakangkan yang namanya nominal. Menurut peneliti, ini merupakan hal yang harus diterapkan dan dicontoh oleh lembaga-lembaga pendidikan lainnya.
Setiap guru yang ingin ikut berjuang untuk mencerdaskan anak-anak bangsa dalam lembaga ini terlebih dahulu diwawancarai mengenai kesiapannya dalam berjihad tanpa memberi tahu nominal yang akan diterimanya, bagi yang dinyatakan lulus maka berhak untuk ikut menjadi salah satu tenaga pendidik di Rumah Tahfizh Miftahul Jannah. Kepribadian tenaga pendidik ini lah yang menjadi salah satu faktor pendukung untuk keberhasilan para santrinya yaitu bagi para santri yang memiliki motivasi dan keinginan yang kuat untuk cepat menyelesaikan hafalan 30 juznya dengan mutqin, maka para ustaz dan ustazahnya siap mentasmi' santrinya kapanpun meski diluar jam belajar tanpa ada honor tambahan.

4. Pimpinan atau ketua yayasan yang selalu aktif

Kebijakan dan ketegasan seorang pemimpin tentu sanga mempengaruhi akan keberhasilan suatu lembaga yang dipimpinnya. Dalam hal ini, menurut peneliti, pimpinan Rumah Tahfizh Miftahul Jannah sangat besar berkontribusi dalam kesuksesan para santri-santri. Baik masalah kecil atau masalah besar atau apapun itu, pimpinan Rumah Tahfizh Miftahul Jannah yaitu ustazah Sri Wahyuni selalu aktiv di dalamnya seperti masalah santri yang tidak mencapai target hafalan atau yang lainnya, pimpinan yayasan selalu ikut serta dalam menyelesaikan berbagai masalah. Bahkan 
pimpinan yayasab juga sering turun langsung dalam memberi motivasi terhadap santri-santrinya. Bahkan bagi santri yang tidak mampu namun memiliki keinginan dan kemauan yang kuat untuk menghafal di gratiskan oleh yayasan.

\section{SIMPULAN}

Ada beberapa metode yang diterapkan di Rumah Tahfzih Miftahul Jannah dalam proses menghafal Alquran yaitu: metode tasmi', wahdah, takrir dan sima'i. metode tasmi' dibagi menjadi dua yaitu tasmi' setoran pada pagi hari dan tasmi' ulangan pada sore hari. Metodetasmi' ini merupakan kegiatan menyetor hafalan alquran santri kepada salah seorang ustaz atau ustzah masing-masing. Adapun metode wahdah, takrir, dan sima'I merupakan metode yang diterapkan oleh santri-santri secara individu untuk mencari hafalan sebelum menyetorkannya kepada ustaz atau ustazahnya.

Faktor-faktor penghambat dan pendukung dalam proses menghafal Alquran di RumahTahfzih Miftahul Jannah yang peneliti temukan diantaranya adalah: 1. Faktorpenghambat: Kurangnya kesungguhan santri dalam menghafal, kurangnya pengawasan terhadap keseharian santri, serta fasilitas yang kurang memadai. 2. Faktor pendukung: kemauan santri yang tinggi, adanya kegiatan ekstrakurikuler santri, serta adanya dukungan dari para tenaga pendidik dan pimpinan atau ketua yayasan yang selalu aktif.

\section{DAFTAR RUJUKAN}

Ahmad Salim Badwilan. (2010). Cara Mudah Bisa Menghafal Alquran. Jogjakarta: Bening

W,Ahsin.(1994). Bimbingan Praktis Menghafal Alquran. Jakarta: Bumi Aksara

Nasional, Departemen Pendidikan. (2005). Kamus Besar Bahasa Indonesi, Jakarta: Balai Pustaka

Moleong, Lexy J. (2005).Metodologi Penelitian Kualitatif, Bandung: PT Remaja Rosdakarya

Yunus, Mahmud. (1990).Kamus ArabIndonesia. Jakarta: Hidakarya Agung

Yayan, Masagus H.A. Fauzan. (2015). Quantum Tahfidz:etodeCepatdanMudahMenghafalA lquran. ttp: Erlangga

Huberman, Matthew B. Miles dan A. Michael. (1992). Analisa Data Kualitatif. Jakarta : UI-Press

Q, Sa'dulloh. S. (2008). 9 Cara Praktis Menghafal Alquran, Jakarta: Gema Insani

Silalahi, Ulber. (2010). Metode Penelitian sosial. Bandung : Refika Aditama

Wahid, Wiwi Alawiyah.(2010). Cara Cepat Bisa Menghafal Alquran. Yogyakarta:Andi Offset 